\title{
Entre los estudios sobre el capitalismo agrario en la Argentina y el Hasta Siempre, Toto Schmucler
}

Héctor Naum Schmucler, el «Toto» como cariñosamente le llamaban no solo sus amigos, fundador y director de esta revista entre 1993 y 2009, falleció en diciembre de 2018 cuando estaba en ciernes la supervisión final de este número. Esta desdicha tiñe el espíritu de este editorial. Permítase, entonces, este breve introito: entrevistado por estudiantes de la revista El Cactus en diciembre de 2013 -publicación vinculada a la carrera de ciencias de la información de la UNC- le preguntan:

- ¿Cómo le gustaría que la historia lo recuerde? Como un semiólogo, un escritor, un padre..., el Toto responde: «Ahora que pienso, está la muerte y están los recuerdos, porque a uno se lo recuerda cuando ya no está. No me gustaría que piensen que era un mal tipo. Pero inmediatamente pienso que nunca voy a saber eso, por lo tanto, cada uno se acordará como quiera o como pueda. Hay gente que trabaja para tener su monumento. Lo que sé es que todo quedará en el olvido, y abi nos unificamos todos, en un gran olvido. En realidad no me preocupa mucho, pero no como un acto de soberbia, sino porque sé que no tiene sentido. Dejémoslo en el olvido, tal vez sea lo más saludable para vivir ahora, antes de moriv, y para los otros que no estén obligados a pensar: «ah, le hubiera gustado que lo recuerden asì. Eso les complace a los vivos. Hasta nuevo aviso, el muerto está muerto. Lo contrario sería, ¿cómo no me gustaría que me recuerden? Ү... no me gustaría que se dijera que era un tramposo, un tramposo intelectualmente. Eso, no me gustaria» ${ }^{1}$

Consciente de la fragilidad de lo humano, no solo eludió las trampas del oportunismo intelectual. Amante del pensamiento crítico e intelectual de frontera entre diversas tradiciones culturales, caminante de los bordes entre la academia, la soledad creativa y el compromiso contra la injusticia -estuvo varias veces preso debido a su militancia en el Partido Comunista del que luego se desencantó para protagonizar la aventu-

${ }^{1}$ El Cactus, (2013), 2 (2). 
ra de la revista Pasado y Presente- y años después exiliado en México, recorrió con pasión y tenacidad el largo camino que lo condujo del pequeño pueblo ferroviario de Hasenkamp en Entre Ríos (donde había nacido en el seno de una familia judía proveniente de la región de Besarabia en la época del imperio zarista) a las cumbres de la reflexión creadora en diálogo con Armand Mattelart, Ariel Dorfman, Julio Cortázar, Eliseo Verón, Oscar del Barco, Carlos Altamirano, Juan Carlos Torre, entre otros. Extrañaremos al Toto, echaremos de menos su reflexión implacable e inconformista, nunca atado a las modas del momento.

En este número, dedicado al capitalismo y la cuestión agraria en la Argentina, se recorre un haz de temas claves del debate contemporáneo, que asocian economía, política, cultura, intereses sectoriales y proyectos de poder. Desde los creyentes en el «destino agrario de la nación» y los partidarios del agro-negocio a las visiones industrialistas, un núcleo de temas atraviesa un debate inconcluso: el desarrollo del capitalismo en el campo, la transformación de sus relaciones de producción, el cambio tecnológico y las economías de escala, las formas de tenencia de la tierra y la reconfiguración de los actores sociales. En su elaboración intervinieron docentes e investigadores de siete universidades nacionales de Córdoba, Río Cuarto, La Plata, Quilmes, Comahue, Nordeste y Buenos Aires, así como becarios e investigadores del CONICET.

Como es de rigor, se incluye asimismo una sección bibliográfica que comprende estudios sobre dos libros de reciente aparición: uno sobre «Mujeres, familia y trabajo. Chacra, caña y algodón en la Argentina (1930-1960)» y otro sobre «La historia argentina en perspectiva local y regional».

César Tcach

Director de Estudios 